minor activity has been reported, and thore is no valid reason for supposing that cruptions will not occur again on Jan Mayen, as they have on Tristan da Cunha. Moraines of an earlier glacier advance are found on top of the Tromsøryggen volcanics. The fossil sea-cliffs, 3,500-4,000 years old, post-date these moraines, so they must represent an ico advance about 4,000 years ago, at the close of the PostPleistocene warmer period.

The late Peter Smith and a team of glaciologists from Imperial College recorded a present-day minor re-advance of Sørbreen in 1959 , and it was in order to extend these observations that a full glaciological survey of the Beerenberg ice was planned for 1961 . Although certain of the high-level projects had to be abandoned as a result of the Joss of the first glaciological team, it was possible to complete detailed observations on Sørbreen and to make a general survey of the other glaciers and of the summit rime domes.

Re-determination of the snout position of Sørbreen revealed a further advance of 124 metres between 1959 and 1961, making a total re-advance of $271 \mathrm{~m}$. since 1949. The glacier has now almost regained its 1938 position. Surface flow measurements at the 130-, 310. and 910-m. stake lines across Sørbreen, made after an interval of between six and seven woeks, produced values ranging from 4 to $40 \mathrm{~cm}$./day, the highest values being recorded from the $900-\mathrm{m}$. line and the lowest from the snout region. Ablation figures ranged from 1 to $5 \mathrm{~cm}$./day. Observations on the other glaciers clearly demonstrate that the readvance of Sørbreen is not an isolated feature, and that the whole Beorenborg ice system is in an active state. Spectacular advances can be seen in numorous placcs, accompanied by thickening of snout areas and the development of large seracs in the lower parts of glaciers.

It is apparent from a comparison of the Jan Mayen evidence with the evidence from other North Atlantic areas that the present Beerenberg ice-field expandod rapidly some 350 years ago. The main glaciers radiating from the mountain made a series of advances culminating about 1750 , when the largest group of modern lateral and terminal moraines were produced. Since that time the glaciers have been in oscillatory retreat, each intervening re-advance reaching less far than its predecossor. Re-advances are thought to have occurred in 1810-20, 1850-70 and 1915-20, each producing its own distinctive moraines. The present-day re-advance began around 1954, and is probably near to its climax. Analysis of the climatic data for Jan Mayen and the surrounding areas reveals a remarkable correlation between glacier fluctuations and the weather patterns in the North Atlantic. There is nothing in the evidence from Jan Mayen to suggest that the current advance, or the present lowering of world temperatures, is more than a temporary regression in the course of the climatic amelioration that has been noticeable since the turn of the century. It seems likely that this long-term amelioration will continue until the climate of the North Atlantic region recovers its milder, pre- 1600 A.D. character.

Extensive rock . collections wore made by the expedition for future petrographic and petrochemical investigation. Specimens were collected by a new technique for palæomagnetic study. A collection of 250 lichens was made for the British Museum (Natural History). Considerable photography was undertaken by the expedition. 'This included a colour ciné film and scientific record photography in black-and-white and colour. A novel camera-head, designed by Peter Smith, and constructed by P. J. D. Guile, made panoramic record photography possible in locations where only an ice-axe was available for support. It was thoroughly tested in the field and proved very satisfactory and useful. Although certain of the more adventurous parts of the mountaineering project had to be abandonod, such as the plan to enter and camp in the summit crater, considerable experience was gained during traverses of the largor glaciers and the ice-field, and on the climb of King Haakon VII Topp $(7,470 \mathrm{ft}$.) made by Birch and Kinsman on August 14 .

${ }^{1}$ Fotherby, R., Purchas His Pilgrimes, ete. (Tondon, 1625). New edition, 13, 31, 14, 82 (Glasgow, 1905-7).

2 Scoresby, W., Jan Mayen Island (Edinburgh, 1820).

${ }^{2}$ Dufferin, Lord., Letters from High Latitudes (London, 1857).

'Wells, J. C., The Gateway to the Polynya (London, 1876).

${ }^{5}$ Wordie, J. M., Geog. J., 59, 180 (1922).

8 Bird, E. G., Geog. J., 85, 553 (1935).

' King, A., Geog. J., 94, 115 (1939).

${ }^{8}$ Russell, R. S., Alpine, J., 51, 18 (1939).

${ }^{9}$ Marshall, A. J., Oxford Univ. Explor. Club Bull., No. 1 (1948).

1" Nicholls, Q. D., Geog. Mag., 92, 127 (1955).

${ }^{11}$ Dollar, A. T. J., Summary Rep. 1959 Univ. Lond. Exp. to Jan Mayen Island, Greenland Sea (Birkbeck College and Imperial College, London, 1959).

12 Boldva, A. B. von., Beobachtungs-Ergebnisse, Wien, BD1, 22 (1886).

${ }^{13}$ Jennings, J. N., Appendix II, ref. 7.

${ }^{14}$ Jennings, J. N., J. Glac., 1, 167 (1948).

${ }^{15}$ Russell, W. S. C., Bull, Amer. Geog. Soc., 5, 43, 881 (1911).

${ }^{16}$ Smith, P., Final Rep. 1959 Univ. Lond. Exped. to Jan Mayen Island (Imperial College Section, Imperial College, London, 1960). 17 Heezen, B. C., and Fwing, M., Proc. First Intern. Symp. Arctic
Geol., Toronlo, 622 (1961).

\title{
NATIONAL RESEARCH ORGANIZATIONS IN SOUTH-EAST ASIA
}

$\mathrm{T}$

HE natural sciences programme of Unesco covers a wide range of activities, among the lesspublicized of which are the science co-operation offices. These offices are facilitating co-operation in scientific work in the developing countries in a very practical way and are showing results which are out of proportion to the all-too-meagre resources allotted to thэm. A recent example of the important work of the South-East Asia Science Co-operation Office was the regional meeting of representatives of national research organizations called by that Office in December 1961 to diseuss problems of the organization of scientific research in the area. It was held at Hong Kong in association with the Golden Jubilee
Celebrations of the University of Hong Kong, and arose from a similar meeting held two years earlier at Bandung (Nature, 186, 859; 1960). Representa. tives of Australia, the Republic of China, Hong Kong, India, Indonesia, Japan, Korea, the Federation of Malaya, Now Zealand, the Philippines, Singapore and Thailand were present. The meeting was inaugurated with an address by the Hon. Sir Sik Nin Chan, who stressed the importance of science and technology in assisting the industrial development of South-Fast Asia and the noed for close collaboration if this was to be achioved. Dr. (now Sir) Lindsay Ride, vice-chancellor of the University of Hong Kong, was elected chairman of the meeting. 
The general theme of the meeting, which had a rather wider aspect than that adopted at Bandung, was concerned with the development of national research policies in the South-East Asia region. The report, Current Trends in Scientific Research (the Auger Report), prepared by Unesco as a result of the resolution of the General Assembly of the United Nations on November 14, 1958, that a survey should be made of the main trends of inquiry in the field of natural sciences and the dissemination and application for peaceful ends of such scientific knowledge, was used as a background document.

The stage of scientific development, as represented by the national research organization, varied considerably in the countries of the area. Some already had large and effective national organizations which had made important contributions to their national development. Other research bodies were in a much earlier stage but had been successfully launched, while in other countries again national organizations had not gone far beyond the planning phase. Detailed accounts were presented of the progress that had been made in the two years which had elapsed since the Bandung meeting. These all reflected an increasing appreciation by Governments of the im. portance of scientific research, and the meeting considered some of the factors which were limiting expansion.

The great variation in the relative expenditures by different Governments was discussed. It was, of course, appreciated that the optimum effort would vary from country to country according to need, and also that the amount of money spent was not necessarily an accurate measure of the amount of research. It was felt, however, that it would be valuable to compare the expenditures of countries of the region as percentages of gross national products or of national budgets and the Unesco Office was asked to obtain and analyse figures for the countries of the area. (The meeting did not feel it would be proper for it to recommend a minimum figure for Government expenditure on research, though one delegate was prepared to go on record that this should be 1 per cent of the national budget.)

The question of extension-making use of research results obtained-should be a vital feature of a national research policy. Although in agricultural research the problems were now fairly generally understood, this was not the case in the industrial field. The translating of results of research to industrial practice was not an activity in which the research scientist was skilled, and various means of doing this (for example, the establishment of development authorities) were discussed. In many countries of the region, however, particularly those just beginning to build up industrial activity, the important need was to provide day-to-day assistance in solving smaller technical problems arising in the course of production - the application of existing basic knowledge and 'know-how'. In New Zealand this had been solved by the establishment of industrial development laboratories, and this principle was being followed by at least one other country in the area.

Although the meeting was primarily concerned with national research organization, it discussed the role of research in universities since the national organizations are dependent on the universities to provide them with trained personnel. It was vital for universities to undertake active research programmes so that students could be trained in methods of research. In some countries it was, of course, the policy to carry out much of the basic research in the universities or other institutes attached to them. In other countries the national research organization played a major part in assisting university research - this was particularly useful where the high cost of research facilities was a problem. In any event, the universities must occupy a position of high status in the national research scheme and there should be the closest collaboration between them and the national research organizations. Although it was emphasized that the responsibility for postgraduate training must be in the university system, it was felt that the recognition by the universities of outstanding scientists in the national research organizations as honorary university officers was most desirable.

Another problem which came under vigorous discussion was that of the promotion of science. In order to secure adequate support for scientific work it is essential that there should be an awareness throughout the community of its aims and objectives and the practical effect it can have in raising living standards and promoting national welfare. This was particularly important in countries in the South-East Asia region and it was agreed that two groups should be considered: Government and general public. If the ministerial head of the national research organization were a senior minister or his equivalent, science could make itself felt much more effectively. In India the fact that the Prime Minister himself was the minister concerned with the national research body had had a tremendous effect on its development. Every possible step should be taken by national research organizations to emphasize the value of investment in scientific research. Use should be made of all the mass media-the Press, films, radio, television, etc., for developing an awareness of science and its results. In particular, the Press reached a great proportion of the public, and provision of informative, well-written material was essential. Writing for this medium was a specialized task, and the number of competent scientific journalists available was very limited. The value of science museums in increasing public awareness of science was also stressed. It was important that young people should be interested at an early age not only to increase their understanding but also to interest them in the attractions of a career in science. The increasing demand for scientific manpower was making this more important, and in discussing this the meeting emphasized two important points. The first of these was the need in most countries for improving science education at the school-level. It would not be possible to attract the brightest children to a scientific career unless the subject was made interesting and exciting from the beginning. This required inspired teaching which would catch the imagination of young people and give them an idea of the excitement of the subject and its practical relevance in improving living standards and social conditions. In many countries the schoolteacher did not enjoy sufficient status to attract men and women of adequate intellectual calibre to the profession. The other point which was emphasized was the need for adequate pay and status for the scientist. In some countries of the area he did not enjoy the same standing as the administrative Civil servant and was obliged to undertake additional employment to ensure an adequate income. In these circumstances, the best minds would never be attracted to a research career, and it was desirable that countries should adopt a scientific policy which would materially improve the status of scientists. 
The meeting emphasized the importance of scientific documentation centres, particularly in developing countries. Such centres had now beon established, with the assistance of Uneseo, in India, Pakistan and the Philippines, whilo one was being set up in Thailand and another planned in Indonesia. It was suggested that it would be impossible for each centre to build up a completely comprehensive service and the Unesco South-East Asia Science Co-operation Office at Djakarta was asked to examine the possibility of elose liaison and co-ordination between the various centres. The Office was also asked to study the possibility of establishing regional scientific journals in the area. Although there was little difficulty in placing scientific papers in international journals in basic subjects like physics and chemistry, it was often hard to provide for publication of papers of specialized regional interest, for example, zoology, parasitology, botany, phytochemistry. Because of cost and limitod output of papers, it was difficult for smaller countries to establish thoir own journals to cater for this type of matorial. Regional journals in such subjects would overcome the difficulties and ensure that the work could be properly recorded and made more readily available by libraries.

The mocting also examined a number of other aspects of co-operation, for example, technical assistance, regional collaboration in research and training, the exchange of scientists, regional scientific meotings, etc. The formal outcome of the meeting was a series of recommendations to the DirectorGeneral of Unesco that the South-East Science
Co-operation Office should indertake a number of specific activities designed to strengthen the development of science in the countries of the region. The meeting also emphasized the importance of the work being carried out by tho Office, which thoroughly justified the provision of additional funds to enable a substantial expansion of its activities.

The South-East Asia region embraces countries the stage of development of which varies over an extremely wide range, and the conference-more effective perhaps because of its small size and intimacy-should make a contribution towards achieving the purpose of the recommondations of the Auger Report: the better utilization of science for improving living standards. This is a goal which is common to the countries of the region, as is evidenced by the establishment or planning of national research organizations by all the Governments concerned. The desire for constructive international co-operation, demonstrated convincingly at this moeting as well as at Bandung, should have important practical results in holping the growth and work of these organizations, particularly in the less-developed countries. It should also have as a secondary, though no less important, consequence, a political dividend in the building up of international trust and confidence. This may be small in relation to the magnitude of international tensions, but it is nevertheless an important aspect of international scientific gatherings, particularly those like that described where there is a common interest in working together for constructive ends. GUY B. GRESFORD

\section{OBITUARIES}

\section{Prof. A. H. Compton}

Arthur Holly Compton died on March 15 in Berkeley, California, as a result of cerebral hæmorrhage suffered two weeks earlier. He was sixty-nine.

He had retired last year as distinguished service professor of natural philosophy in Washington University (St. Touis), where he had served as chancellor from 1945 until 1953 . He was planning to be active in retirement as professor-at-large between Washington University, the University of California (Berkeley) and the College of Wooster (Ohio), and had gone to Berkeley to deliver a lecture series on "Man, Science and Society".

Compton roceived his B.Se. from the College of Wooster, where his father, Elias Compton, was professor of philosophy, and received his Ph.D. in 1916 at Princeton University. The next year he was an instructor at the University of Minnesota, and then was for two years a research ongineer for the Westinghouse Lamp Company in Pittsburgh. 'The year 1919-20 was spent at Cambridge (England) as a National Research Fellow, after which he was appointed Wayman Crow professor and head of the Department of Physies at Washington University, where he remained until 1923. During 1923-45 he scrved as professor of physies and dean of physical sciences at the University of Chicago, until he returned to Washington University as chancellor in 1945. He was president of the American Physical Society in 1934, of the American Association of Scientific Workers in 1939-40 and of the American Association for the Advancement of Science in 1942. In 1927 he shared the Nobel Prize in physics with C. T. $R$. Wilson.

His career was marked by an extraordinary range of great accomplishments in physics, in higher education, in war-time scientific research, and in efforts to improve human and international relations.

While a student at Princeton he devised a beautiful demonstration of the Earth's rotation, which ought to be known to all teachers of physics. A toroidal glass tube is filled with water, and mounted so that it can be 'flipped' through $180^{\circ}$ about a diameter as axis. Before flipping, the water is at rest relative to the tube, which is turning, relative to the fixed stars, in its own plane with the component of the Earth's rotational angular velocity normal to that plane. After flipping, the water drifts relative to the tubs, at a rate proportional to that angular velocity component. By measuring the drifts produced by three successive flips about each of three mutually perpendicular axes, one finds the Earth's angular velocity as a vector; that is, one can infer which local direction is north, what is the observer's latitude, and what is the absolute value of the length of the day.

His first major discovery was the detailed measurement and interpretation of the wave-length change occurring when X-rays are scattcred, especially by materials of low atomic number. This is now gonerally known as the Compton effect. He showed that the loosely bound electrons in the material scatter the $\mathrm{X}$-rays in accordance with the principles of conservation of momentum and energy, as if thoy consist of a stream of photons, each having momentum 